JRPB, Vol. 7, No. 2, September 2019, Hal. 239-248

DOI: $10.29303 / \mathrm{jrpb} . v 7 \mathrm{i} 2.142$

ISSN 2301-8119, e-ISSN 2443-1354

Tersedia online di http://jrpb.unram.ac.id/

\title{
PENGARUH PERBANDINGAN VOLUME PELARUT PADA KRISTALISASI \\ PATCHOULI ALCOHOL DARI MINYAK NILAM (Pogostemon cablin Benth) DENGAN METODE COOLING CRYSTALLIZATION
}

\author{
Effects of Solvent Volume Ratio on Patchouli-Alcohol Crystallization in Patchouli \\ Oil (Pogostemon cablin Benth) with Cooling Crystallization Method
}

\section{Laily Rizki Safira $^{1}$, Asri Widyasanti ${ }^{1 *}$ Sarifah Nurjanah $^{1}$}

${ }^{1}$ Departemen Teknik Pertanian dan Biosistem, Universitas Padjadjaran Jl.

Raya Bandung Sumedang km 21, Jatinangor 40600

$$
\text { Email }^{*} \text { : asriwidyasanti@gmail.com }
$$

\begin{abstract}
Patchouli oil is one of Indonesia's mainstay essential oil commodities that is very perspective on the market. On the patchouli alcohol crystallization process it is necessary to do optimization to obtain yield and quality of patchouli alcohol crystals by using a solvent. The objective of this study was to determine the effects of the solvent ratio in the patchouli alcohol crystallization process on yield and quality of crystals obtained. The research method used was descriptive method with correlation-regression analysis. This process started with a patchouli oil vacuum fractionation distillation process to increase the level of patchouli alcohol in a distillate. On the crystallization process, five solvent variables condition were used, namely 10\%, 20\%, 30\%, 40\%, and 50\% and control treatment. The parameters observed were the yield and quality of patchouli alcohol crystals, consist of color evaluation, bulk density, true density, and melting point. The largest crystal yield and yield in the treatment of $10 \%$ solvent volume were $52.77 \%$ and $87.93 \%$. The best quality value obtained from the color (hue) evaluation on the treatment of $50 \%$ solvent volume was 100.0533, bulk density on $10 \%$ solvent volume was 0.4351 $\mathrm{g} / \mathrm{mL}$, true density on $30 \%$ solvent volume were $1.0011 \mathrm{~g} / \mathrm{mL}$, and melting point on $40 \%$ solvent volume were $57^{\circ} \mathrm{C}$
\end{abstract}

Keywords: crystallization, patchouli alcohol, the solvent volume ratio

\begin{abstract}
ABSTRAK
Minyak nilam merupakan salah satu komoditas minyak atsiri andalan Indonesia yang sangat prospektif di pasaran. Untuk meningkatkan mutu minyak nilam yaitu dengan menghasilkan kandungan patchouli alcohol yang tinggi. Pada proses kristalisasi patchouli alcohol perlu dilakukan optimalisasi untu sekali mendapatkan rendemen dan mutu patchouli alcohol yaitu dengan menggunakan pelarut. Penelitian ini bertujuan untuk mengetahui pengaruh perbandingan pelarut dalam proses kristalisasi patchouli alcohol terhadap rendemen dan mutu kristal yang dihasilkan. Metode penelitian yang digunakan adalah metode deskriptif dengan analisis korelasi-regresi. Penelitian ini diawali dengan
\end{abstract}


proses distilasi fraksinasi vakum minyak nilam untuk meningkatkan kadar patchouli alcohol dalam distilat. Pada proses kristalisasi digunakan lima kondisi variabel pelarut yaitu 10\%, 20\%, 30\%, 40\%, dan 50\% dan satu perlakuan kontrol. Pengamatan yang dilakukan yaitu rendemen dan mutu kristal patchouli alcohol meliputi uji warna, bulk density dan partikel density, dan melting point. Nilai rendemen kristal dan yield terbesar pada perlakuan volume pelarut $10 \%$ yaitu $52,77 \%$ dan $87,93 \%$. Perolehan mutu yang terbaik yaitu uji warna (nilai Hue) pada perlakuan volume pelarut $50 \%$ sebesar 100,0533 , bulk density pada perlakuan volume pelarut $10 \%$ sebesar $0,4351 \mathrm{~g} / \mathrm{mL}$, true density pada perlakuan $30 \%$ sebesar $1,0011 \mathrm{~g} / \mathrm{mL}$, melting point pada perlakuan $40 \%$ sebesar $57^{\circ} \mathrm{C}$.

Kata Kunci: kristalisasi, patchouli Alcohol, perbandingan volume pelarut

\section{PENDAHULUAN}

\section{Latar Belakang}

Indonesia memiliki kekayaan alam berupa sumber daya hayati maupun nonhayati, selain terkenal dengan hasil rempah-rempahnya yang melimpah, Indonesia juga terkenal dengan minyak atsirinya. Minyak atsiri merupakan senyawa yang umumnya berwujud cairan dan diperoleh dari bagian tanaman yaitu akar, batang, daun, kulit, buah, biji, dan bunga. Bagian dari tanaman nilam yang diekstrak pada umumnya adalah bagian daun dengan dicampur bagian batang untuk memudahkan proses pengeluaran minyak dari daun. Metode ekstraksi yang paling banyak digunakan adalah metode penyulingan dengan uap air atau dengan uap panas (Nurjanah, dkk., 2017).

Indonesia memiliki 40 jenis minyak atsiri yang dapat diproduksi dari 150 jenis minyak yang diperdagangkan di pasar dunia. Sentra penghasil tanaman nilam terbesar di Indonesia terdapat di NAD, Sumatera Utara, Sumatera Barat, Bengkulu, Sumatera Selatan, Jawa Barat, Jawa Tengah, dan Jawa Timur. Beberapa daerah juga mulai mengembangkan nilam seperti Sulawesi Selatan, Kalimantan Timur, dan Kalimantan Tengah (Dewan Atsiri Indonesia dan IPB, 2009). Meskipun banyak jenis minyak atsiri yang bisa diproduksi di Indonesia, baru sebagian kecil jenis minyak atsiri yang telah berkembang dan sedang dikembangkan di Indonesia (Setiyowati dan Fitri, 2012).

Tanaman nilam memiliki prospek pasar yang cukup baik dan paling luas jika dibandingkan dengan tanaman penghasil minyak atsiri lainnya. Selain itu, dari transaksi perdagangan domestik dan jalur ekspor, jenis minyak nilam menempati urutan teratas dalam jumlah dan volume transaksi. Menurut Armando (2009), tanaman nilam (Pogostemon cablin Benth), salah satu tanaman penghasil minyak atsiri yaitu minyak nilam yang merupakan komoditas ekspor utama sebagai penghasil devisa negara.

Petani nilam hanya mampu menghasilkan minyak nilam dengan kandungan patchouli alcohol 26-28\%, sedangkan pabrik penyulingan dengan peralatan suling yang terbuat dari bahan baja anti karat mampu menghasilkan minyak nilam dengan kandungan patchouli alcohol 31-35\% (Sarwono,1998). Minyak nilam yang semula diproduksi di Indonesia hanya menghasilkan minyak nilam kotor dengan rendemen minyak $<3 \%$ dan kadar patchouli alcohol $<32 \%$, maka minyak nilam kotor atau crude patchouli oil yang diekspor dengan harga murah hendaknya dimurnikan (refinement) di Indonesia, kemudian diekspor langsung ke Eropa, USA, Jepang tanpa harus melalui Singapura dengan harga yang lebih mahal (Mahfud dan Bhuana, 2010). Padahal kandungan patchouli alcohol dalam minyak nilam dapat dimaksimalkan sampai $40-50 \%$. 
Fungsi utama dari minyak nilam yaitu sebagai bahan baku (fiksatif) dari kandungan senyawa utamanya yaitu patchouli alkohol dan sebagai bahan eteris untuk wewangian parfum agar aroma keharumannya bertahan lebih lama. Penelitian Nurjanah, dkk., (2016), menunjukkan bahwa minyak nilam berpotensi untuk dikembangkan sebagai bahan antibakteri alami. Kegunaan minyak nilam juga banyak dipakai sebagai aromaterapi. Kandungan yang terdapat dalam nilam dapat membantu mengurangi kegelisahan dan depresi, mengendalikan nafsu makan, menenangkan saraf, mengurangi kecemasan, ketegangan dan insomnia yang pada akhirnya dapat digunakan sebagai terapi psikis (Armando, 2009).

Patchouli alcohol dalam minyak nilam dapat dipisahkan dari komponen lainnya dengan metode fraksinasi destilasi. Pemisahan komponen pada metode ini berdasarkan adanya perbedaan titik didih dari masing-masing komponen yang akan dipisahkan (Nurjanah, dkk., 2017). Beberapa peneliti telah mengembangkan metode kristalisasi diantaranya metode isolasi dan purifikasi patchouli alcohol dari minyak nilam untuk meningkatkan nilai tambah produk. Patchouli alcohol memiliki nilai komersil yang sangat tinggi sehingga berpotensi untuk dikembangkan. Destilasi fraksinasi pemurnian patchouli alcohol dari minyak nilam bisa mencapai sebesar $92 \%$.

Kombinasi metode destilasi fraksinasi dengan kristalisasi mampu menghasilkan kristal patchouli alcohol dengan kemurnian yang tinggi. Pada proses kristalisasi, supersaturasi atau kondisi lewat jenuh sangat berperan besar, karena pada kondisi ini akan menginisasi terbentuknya inti kristal (nukleasi) dan mempengaruhi perubahan inti kristal menjadi kristal (pertumbuhan kristal). Ada berbagai cara untuk membuat kondisi lewat jenuh atau supersaturasi yaitu dengan cara pendinginan, penguapan pelarut, penambahan pelarut ketiga dan reaksi kimia.

Secara umum untuk supersaturasi pada proses kristalisasi senyawa organik menggunakan metode pendinginan. Terdapat beberapa metode pendinginan yang biasanya digunakan, yaitu dengan metode laju pendinginan alami (natural cooling), laju pendinginan linier (linear cooling) dan laju pendinginan yang terkontrol (controlled cooling) (Tung, dkk., 2009).

Dari beberapa metode kristalisasi, metode cooling crystallization merupakan metode pendinginan yang mudah diaplikasikan dan mampu memproduksi kristal yang berkualitas (Hojjati dan Rohani, 2005). Penelitian mengenai minyak nilam menjadi kristal sudah banyak dikembangkan untuk meningkatkan kadar patchouli alcoholnya. Menurut Nurjanah dkk., (2017), salah satu upaya untuk meningkatkan nilai tambah nilam sehingga dapat meningkatkan harga jual adalah dengan melakukan rekayasa proses untuk menghasilkan produk hilir minyak nilam, yaitu nilam kristal. Nilam kristal adalah nilam yang berkadar patchouli alcohol lebih dari $70 \%$ kemudian dilakukan proses pengkristalan.

\section{Tujuan}

Tujuan dari penelitian ini adalah untuk mengetahui pengaruh perbandingan volume pelarut dan mutu (warna, densitas, dan melting point) dalam kristalisasi patchouli alcohol terhadap rendemen yang dihasilkan.

\section{METODE PENELITIAN}

\section{Alat dan Bahan}

Bahan baku utama yang digunakan pada penelitian ini yaitu minyak nilam Garut, sedangkan bahan kimia yang digunakan yaitu dietil eter, aquades, toluene.

Alat yang digunakan untuk proses 
distilasi fraksinasi minyak nilam adalah $B / R \quad$ Instrument-Spinning Band Distillation System Model 36-100 dan untuk proses kristalisasi patchouli alcohol adalah magnetic stirrer yang dilengkapi dengan hot plate, ruang pendingin, corong buchner yang dilengkapi dengan pompa vakum. Alat-alat yang digunakan untuk analisis mutu kristal patchouli alcohol antara lain Spectrofotometer Colorflex EZ, melting point BUCHI M-565, gelas ukur, pipet tetes, erlenmeyer.

\section{Metode}

Metode yang digunakan pada penelitian ini adalah metode deskriptif dengan analisis korelasi-regresi. Proses kristalisasi patchouli alcohol menggunakan distilat minyak nilam 15 $\mathrm{mL}$ dengan lima perbandingan rasio pelarut $10 \%, 20 \%, 30 \%, 40 \%, 50 \%$ dan satu perlakuan kontrol (tanpa pelarut) yang dilakukan pengulangan sebanyak tiga kali.

\section{Tahapan Penelitian \\ Persiapan Bahan Baku}

Tahapan pertama yang dilakukan yaitu proses persiapan bahan baku minyak nilam yang akan digunakan dalam penelitian. Selanjutnya persiapan bahan kimia dan alat yang akan digunakan dalam penelitian, seperti pembersihan dan pemastian kondisi alat dan memastikan bahan yang akan digunakan agar sesuai standar dan dapat digunakan untuk penelitian.

\section{Proses Distilasi Fraksinasi Minyak Nilam}

Proses distilasi fraksinasi dilakukan dengan menggunakan $B / R$ Instrument Spinning Band Distillation System Model 36-100. Jumlah sampel minyak nilam yang digunakan pada setiap kali ulangan adalah sebanyak $200 \mathrm{~mL}$ yang dimasukkan ke dalam labu didih yang yang terhubung dengan kolom fraksinasi sepanjang $90 \mathrm{~cm}$. Sampel pada labu didih dipanaskan dengan mantel pemanas. Selanjutnya menyalakan sistem kondenser, dimana sistem ini harus dialiri dengan air untuk mengondensasikan fase gas pada bagian distilat.

Proses distilasi fraksinasi berlangsung dalam keadaan vakum yang dikondisikan oleh pompa vakum. Jika sistem sudah siap untuk beroperasi, maka pada program kontrol diatur kondisi proses yang digunakan. Setelah kondisi proses diatur sesuai dengan rencana distilasi, selanjutnya menyalakan pompa vakum dan menjalankan proses distilasi fraksinasi. Pemurnian minyak nilam dengan destilasi fraksinasi vakum berdasarkan penelitan Hashilah (2017). Kondisi proses distilasi fraksinasi secara lengkap disajikan pada tabel 1.

Tabel 1. Kondisi Operasi Distilasi Fraksinasi

\begin{tabular}{lcc}
\hline $\begin{array}{l}\text { Variabel } \\
\text { Proses }\end{array}$ & $\begin{array}{c}\text { Nilai yang } \\
\text { Digunakan }\end{array}$ & Satuan \\
\hline $\begin{array}{l}\text { Run Pressure } \\
\text { Initial Heat }\end{array}$ & 1 & $\mathrm{mmHg}$ \\
Equilibration & 20 & $\%$ \\
Time & 15 & Menit \\
Cut 1 & & \\
Cut 2 & $230-283$ & ${ }^{\circ} \mathrm{C}$ \\
Cut 3 & $283-290$ & ${ }^{\circ} \mathrm{C}$ \\
Heat Rate & $290-300$ & ${ }^{\circ} \mathrm{C}$ \\
Condenser Tempt. & 17 & $\%$ \\
Reflux Ratio & 35 & ${ }^{\circ} \mathrm{C}$ \\
\hline Sunt: Hashillah, 2017 & & \\
\hline
\end{tabular}

Sumber: Hashillah, 2017

Proses Kristalisasi Patchouli alcohol

Hasil distilat dari proses fraksinasi selanjutnya dilakukan proses kristalisasi dengan memasukkan distilat minyak nilam $15 \mathrm{~mL}$ dan menambahkan pelarut 'dietil eter. Secara lengkap kondisi proses terdapat pada Gambar 1. 

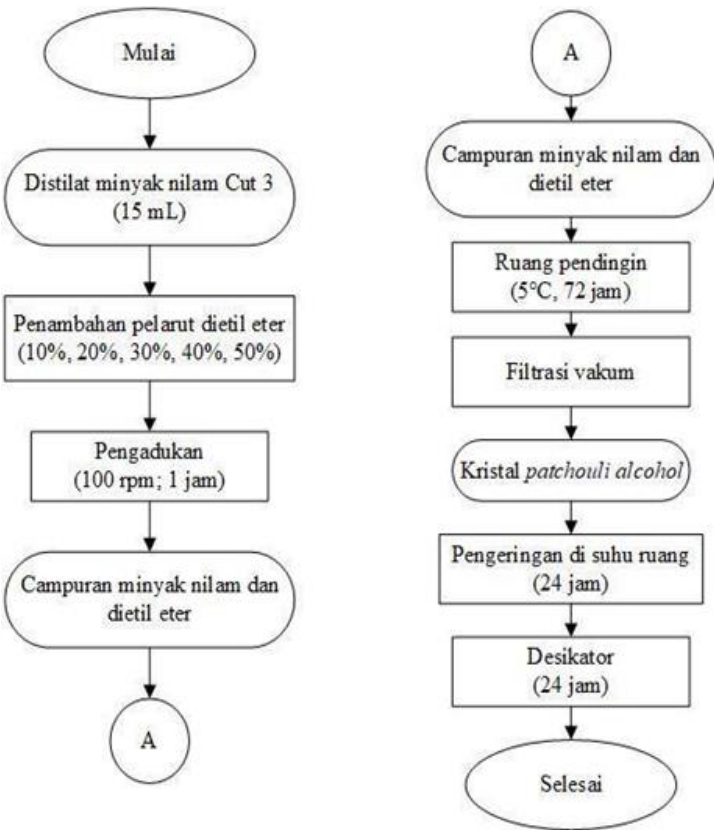

Gambar 1. Diagram Alir Proses Kristal Patchouli Alcohol

\section{Analisis Mutu Minyak Nilam dan Kristal Patchouli Alcohol}

Distilat minyak nilam yang dihasilkan dari proses distilasi fraksinasi vakum dianalis mutunya berupa kadar patchouli alcohol, sedangkan analisis mutu kristal patchouli alcohol yang dilakukan uji warna, bulk density, true density, dan melting point.

\section{HASIL DAN PEMBAHASAN}

\section{Karakteristik Bahan Baku}

Minyak nilam yang digunakan sebagai bahan baku berasal dari Garut. Kandungan patchouli alcohol awal minyak nilam Garut, yaitu 32,30\%. Untuk meningkatkan kadar patchouli alcohol yang terdapat dalam minyak nilam dilakukan proses distilasi fraksinasi vakum. Pemisahan komponen-komponen minyak nilam dilakukan berdasarkan perbedaan titik didih yang dibagi menjadi tiga Cut yaitu Cut $1\left(230-283^{\circ} \mathrm{C}\right)$, Cut 2 $\left(283-290^{\circ} \mathrm{C}\right)$, dan Cut $3^{\circ} \mathrm{C}\left(290-300^{\circ} \mathrm{C}\right)$. Setiap kali proses dilakukan pada tekanan vakum 1 atm.

\section{Rendemen Distilasi Fraksinasi Minyak Nilam}

Rendemen proses distilasi fraksinasi minyak nilam merupakan rendemen yang dihasilkan dari minyak nilam murni hasil penyulingan hingga proses distilasi fraksinasi selesai. Berdasarkan hasil perhitungan rendemen distilasi fraksinasi yang dilakukan yaitu $56,26 \%$ untuk $C u t 1$, 8,7\% untuk Cut 2, dan 21,1\% untuk Cut 3 seperti yang disajikan pada Gambar 2 .

Rendemen tertinggi terdapat pada Cut 1, kemudian Cut 3, dan yang terendah adalah $C u t 2$. Hal ini menandakan bahwa komponen yang berada di rentang suhu $\mathrm{cut}$ $1\left(230-283{ }^{\circ} \mathrm{C}\right)$ jumlahnya lebih banyak dibandingkan dengan komponen yang berada di Cut 2 dan cut 3 . Besarnya jumlah rendemen yang dihasilkan juga dipengaruhi oleh lamanya waktu distilasi pada cut tersebut. Dimana pada Cut 1 membutuhkan waktu 5-6 jam, cut 2 selama 1-2 jam, dan Cut 3 selama 2-3 jam.

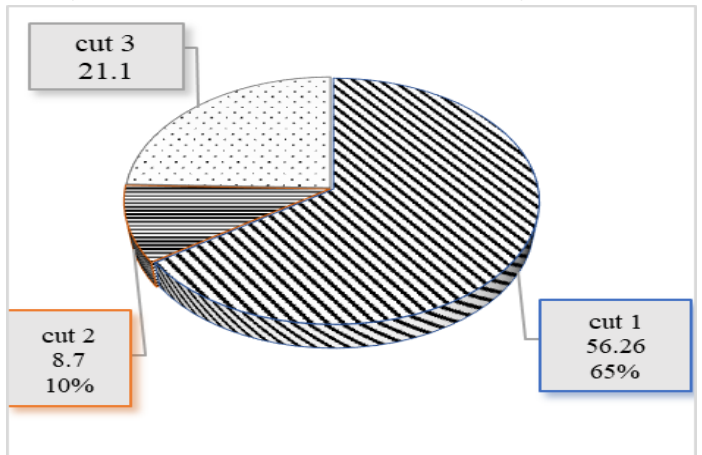

Gambar 2. Grafik Rendemen Distilasi Minyak Nilam

\section{Patchouli Alcohol}

Persyaratan mutu minyak nilam yang terdapat pada SNI 06-2385-2006 menyatakan bahwa kadar patchouli alcohol tidak boleh kurang dari $30 \%$. Berdasarkan hasil pengukuran menggunakan GC-MS , diketahui kandungan patchouli alcohol Cut 1, Cut 2, Cut 3, dan residu secara berturut-turut adalah 2,34\%, 47,85\%, 60,04\%, dan $39,02 \%$.

Kadar patchouli alcohol yang tertinggi terdapat pada Cut 3 yaitu 60,04\% yang digunakan untuk proses kristalisasi. Patchouli alcohol merupakan indikator 
penentuan kualitas dari minyak nilam. Sehingga, dapat dikatakan bahwa semakin tinggi kadar patchouli alcohol dalam minyak nilam, maka mutu minyak nilam semakin baik.

\section{Proses Kristalisasi Patchouli alcohol}

Proses kristalisasi dimulai dengan menambahkan hasil fraksinasi Cut 3 sebanyak $15 \mathrm{~mL}$ yang dicampurkan dengan dietil eter dengan perbandingan pelarut $10 \%, 20 \%, 30 \%, 40 \%, 50 \%$ dan perlakuan kontrol tanpa penambahan pelarut. Pencampuran distilat minyak dengan dietil eter dilakukan dengan menggunakan proses pengadukan. Proses pengadukan dapat mempercepat proses pembentukan kristal. Proses kristalisasi menggunakan suhu pendingin $5^{\circ} \mathrm{C}$, saat larutan didinginkan maka molekulmolekul senyawa terlarut akan saling menempel tumbuh menjadi kristal-kristal yang akan mengendap di dasar botol kaca, sedangkan kotoran-kotoran yang terlarut tidak akan ikut mengendap.

\section{Pengaruh Persentase Pelarut Terhadap Rendemen dan Yield Kristal}

Rendemen kristalisasi patchouli alcohol merupakan rendemen yang dihasilkan dari proses pengadukan hingga proses filtrasi, sedangkan yield merupakan perbandingan massa kristal yang terbentuk dengan komponen yang terkandung didalamnya. Hasil rendemen kristal patchouli alcohol dan yield disajikan dalam grafik pada Gambar 3 dan Gambar 4.

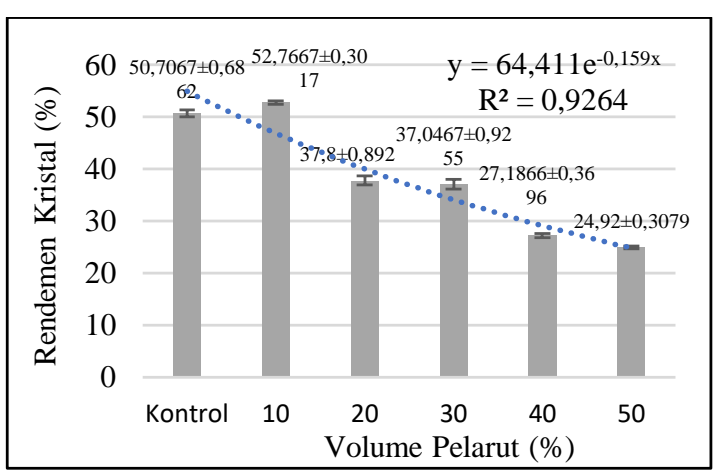

Gambar 3. Grafik rendemen kristal PA

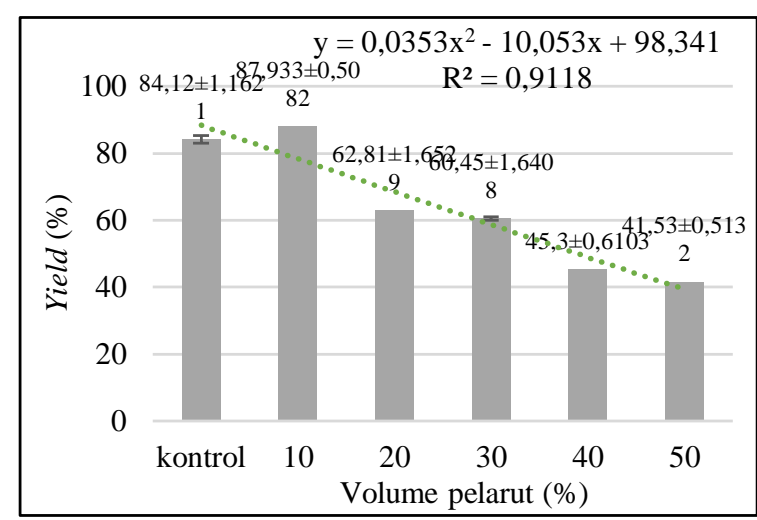

Gambar 4. Grafik Yield

Rendemen kristal dan yield terbesar adalah pada perlakuan pelarut $10 \%$ yaitu $52,77 \%$ dan $78,87 \%$, sedangkan rendemen kristal dan yield yang terkecil adalah pada perlakuan pelarut $50 \%$ yaitu $24,92 \%$ dan $38,94 \%$. Hal ini menunjukkan bahwa semakin banyak pelarut yang digunakan maka kristal yang didapatkan semakin sedikit. Menurut Widyanto dan Nugroho (2010), hal tersebut dapat terjadi karena kelarutan zat pengotor (impurities) dari kristal patchouli alcohol pada dietil eter lebih besar jika dibandingkan dengan kristal patchouli alcohol-nya sendiri.

Nilai determinasi $\left(\mathrm{R}^{2}\right)$ dari rendemen kristal menggunakan persamaan power sebesar 0,9264 dan nilai regresi sebesar 0,9625 atau $96,25 \%$, sedangkan nilai determinasi $\left(\mathrm{R}^{2}\right)$ dari yield menggunakan persamaan polynomial sebesar 0,9118 dan nilai regresi sebesar 0,9549 atau 95,49\%. Dimana nilai regresi rendemen kristal dan yield berada di rentang 0,91 - 0,99 yang berarti memiliki keeratan sangat kuat.

\section{Mutu Kristal Patchouli Alcohol \\ a. Warna}

Uji warna kristal patchouli alcohol dilakukan dengan menggunakan alat Hunter Lab. Spektrofotometer Colorflex EZ. Pengukuran uji warna dilakukan pada seluruh pengulangan sampel nilai ${ }^{\circ} \mathrm{HUE}$. Hasil pengujian warna kristal untuk seluruh sampel didapatkan nilai ${ }^{\circ} \mathrm{HUE}$ berada dalam kisaran warna kromatis yang sama, yaitu kuning. Secara lengkap hasil 
pengukuran warna kromatis kristal patchouli alcohol pada Tabel 2.

Nilai L* merupakan parameter yang menunjukkan tingkat kecerahan bahan, dimana 0 menunjukkan warna hitam dan 100 menunjukkan warna putih. Berdasarkan hasil pengujian pada Gambar 5 , nilai $\mathrm{L}^{*}$ tertinggi yaitu pada perlakuan kontrol 73,80 dan yang terendah pada perlakuan volume $40 \%$ yaitu 66,6 . Nilai determinasi $\left(\mathrm{R}^{2}\right)$ dari persamaan polynomial yaitu 0,033 dan nilai regresi yang dihasilkan sebesar 0,1819 atau

Tabel 2. Warna Kristal Patchouli Alcohol

\begin{tabular}{llcccl}
\hline Perlakuan & $\mathbf{L}^{*}$ & $\mathbf{a}^{*}$ & $\mathbf{b}^{*}$ & $\mathbf{H U E}^{\circ}$ & $\begin{array}{l}\text { Warna } \\
\text { Kromatis }\end{array}$ \\
\hline Kontrol & 73,81 & $-1,09$ & 4,70 & 103 & $\begin{array}{l}\text { Yellow } \\
(Y)\end{array}$ \\
$10 \%$ & 46,04 & $-1,77$ & 7,46 & 103,42 & $\begin{array}{l}\text { Yellow } \\
(Y)\end{array}$ \\
$20 \%$ & 66,92 & $-1,35$ & 5,65 & 101,80 & $\begin{array}{l}\text { Yellow } \\
(Y)\end{array}$ \\
$30 \%$ & 67,83 & $-1,09$ & 5,39 & 101,34 & $\begin{array}{l}\text { Yellow } \\
(Y)\end{array}$ \\
$40 \%$ & 66,6 & $-1,18$ & 6,03 & 100,86 & $\begin{array}{l}\text { Yellow } \\
(Y)\end{array}$ \\
$50 \%$ & 63,25 & $-1,11$ & 6,40 & 100,05 & $\begin{array}{l}\text { Yellow } \\
(Y)\end{array}$ \\
\hline & & & & &
\end{tabular}

18,19\% yang berarti memiliki keeratan sangat lemah karena berada pada rentang 0,00-0,20.

Nilai $a^{*}$ menunjukkan warna kromatis dari hijau sampai merah, dimana a+ menyatakan warna merah dari 0 hingga 100, sedangkan a- menyatakan warna hijau dari 0 hingga -70 . Berdasarkan Gambar 24, nilai a pada semua perlakuan perbandingan pelarut yang dihasilkan minus yang berarti semua perlakuan memiliki warna kromatis hijau. Nilai $a^{*}$ tertinggi pada perlakuan volume $10 \%$ yaitu -1,77 dan yang terendah pada perlakuan kontrol -1,09. Nilai determinasi $\left(\mathrm{R}^{2}\right)$ dari persamaan polynomial adalah 0,248 , sedangkan nilai regresi yang dihasilkan sebesar 0,4979 atau $49,79 \%$ yang berada pada rentang $0,41-0,70$ berarti memiliki keeratan kuat antara volume pelarut dengan nilai a*.

Nilai $b^{*}$ menunjukkan warna kromatis biru dan kuning, dimana $b+$ adalah kuning (yellow) dan b- adalah biru (blue). Berdasarkan hasil pengujian pada Gambar 5 terlihat bahwa nilai $b^{*}$ pada seluruh perlakuan bernilai positif $(+)$ yang berarti memiliki warna kromatis kuning, nilai $b^{*}$ tertinggi pada perlakuan volume $10 \%$ yaitu 7,46 dan yang terendah pada perlakuan kontrol yaitu 4,6967. Nilai determinasi $\left(\mathrm{R}^{2}\right)$ dari persamaan power yaitu 0,142 dan nilai regresi yang dihasilkan sebesar 0,3768 atau $37,68 \%$
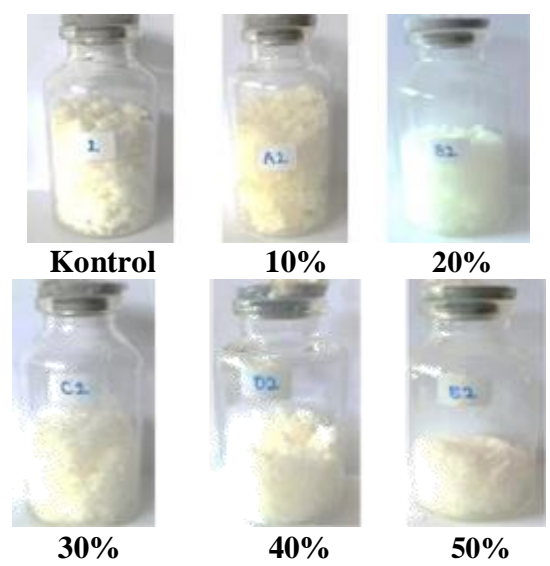

Gambar 5. Warna Kristal Patchouli Alcohol

yang berada pada rentang $0,21-0,40$ berarti memiliki keeratan lemah.

Nilai ${ }^{\circ}$ HUE tertinggi terdapat pada perlakuan volume $10 \%$ dengan nilai 103,42 dan yang terendah pada perlakuan volume $50 \%$ dengan nilai 100,05 . Kristal yang dihasilkan pada perlakuan perlarut $10 \%$ memiliki warna yang lebih kuning jika dibandingkan dengan penggunaan pelarut $50 \%$, dapat dilihat pada Gambar 5 . Nilai koefisien determinasi $\left(\mathrm{R}^{2}\right)$ dari persamaan linear sebesar 0,9132 dan nilai regresi hasil pengujian warna pada keenam perlakuan adalah 0,9556 atau 95,56\% dimana nilai tersebut berada pada rentang $0,91-0,99$ artinya keterkaitan antara volume pelarut dengan nilai $\mathrm{HUE}^{\circ}$ sangat kuat. Terjadinya perbedaan warna pada setiap perlakuan dipengaruhi oleh banyak volume pelarut yang digunakan, semakin banyak pelarut yang digunakan warna yang dihasilkan semakin putih. 


\section{b. Densitas Kristal Patchouli alcohol (True Density dan Bulk Density)}

Kualitas suatu bahan dapat diketahui dari beberapa cara, salah satunya densitas yang merupakan gambaran berat bahan per satuan volume. Pengukuran densitas kristal patchouli alcohol terdiri dari bulk density dan true density. Menurut Rahman (2009), bulk density digunakan untuk mengukur suatu material yang dikemas dalam jumlah tertentu dengan menempatkan massa partikel ke dalam suatu tempat yang volumenya diketahui. Grafik korelasi antara bulk density dengan volume pelarut dapat dilihat pada Gambar 6.

Nilai bulk density terbesar pada perlakuan volume $10 \%$ yaitu $0,4351 \mathrm{~g} / \mathrm{mL}$ dan yang terendah pada perlakuan volume $40 \%$ yaitu $0,2861 \mathrm{~g} / \mathrm{mL}$. Perbedaan nilai bulk density pada setiap perlakuan dipengaruhi oleh bentuk dan ukuran kristal yang dipadatkan. Nilai bulk density yang tinggi berarti kristal tersebut memiliki kemampuan memadatkan yang tinggi jika dibandingkan dengan perlakuan yang lain. Semakin halus atau semakin kecil ukuran partikel kristal maka semakin sedikit ruang yang tersisa. Nilai bulk density yang tinggi maka porositas pada kristal akan semakin kecil. Nilai koefisien determinasi (R2) dari persamaan polynomial untuk bulk density adalah 0,331 , sedangkan nilai regresinya 0,575. Nilai regresi bulk density berada pada rentang $0,41-0,70$ memiliki keeratan kuat.

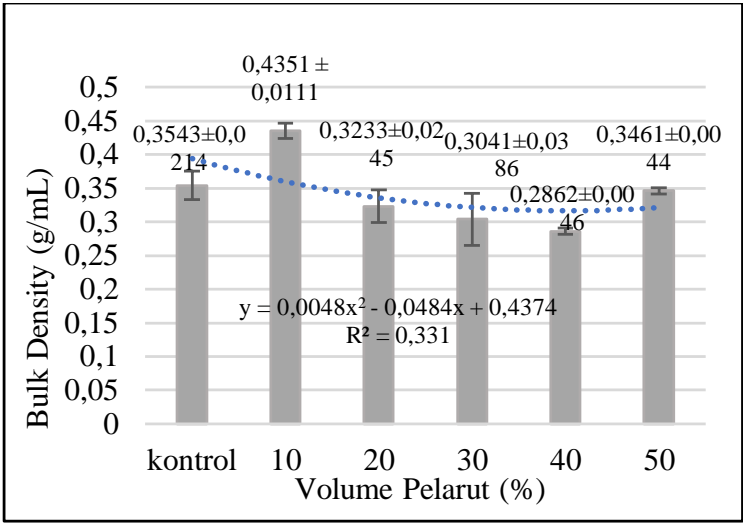

Gambar 6. Grafik Hasil Pengukuran Bulk Density

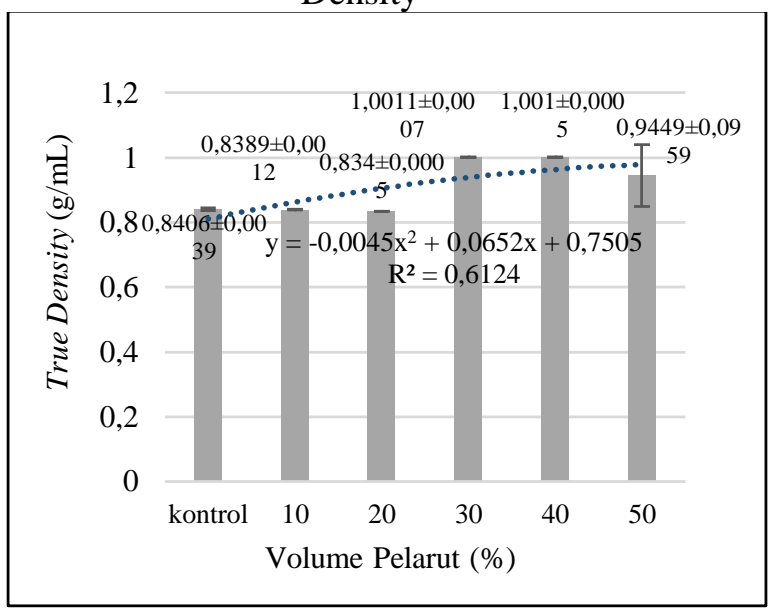

Gambar 7. Grafik Hasil Pengukuran True Density

True density digunakan untuk mengukur densitas bahan yang sebenarnya dimana tidak ada rongga antara partikelpartikel yang terkandung didalamnya. Nilai true density terbesar pada perlakuan pelarut $40 \%$ yaitu $1,011 \mathrm{~g} / \mathrm{mL}$ dan yang terendah pada perlakuan $20 \%$ yaitu 0,8340 $\mathrm{g} / \mathrm{mL}$. Nilai true density yang tinggi maka porositas pada kristal akan semakin kecil.

Grafik korelasi antara true density dengan volume pelarut dapat dilihat pada Gambar 7. Nilai koefisien determinasi $\left(\mathrm{R}^{2}\right)$ dari persamaan polynomial yaitu 0,6124 dan nilai regresinya 0,7825 . Nilai regresi true density berada pada rentang 0,71-0,90 artinya jenis relasi keeratan kuat antara volume pelarut dengan nilai true density yang dihasilkan yaitu sebesar $78,25 \%$. 


\section{b. Titik Leleh (Melting Point)}

Menurut Guenther (1990), kristal patchouli alcohol mempunyai titik leleh sekitar $56^{\circ} \mathrm{C}$. Mengetahui titik leleh dari suatu bahan maka akan dapat diketahui apakah zat tersebut murni atau sudah terkontaminasi dengan pengotoran zatzat lainnya. Apabila zat tersebut murni maka dalam pengukuran titik lelehnya hasilnya akan sesuai yang tertera di dalam literatur. Berdasarkan hasil pengujian titik leleh kristal patchouli alcohol, titik leleh tertinggi yaitu pada perlakuan $40 \%$ sebesar $57^{\circ} \mathrm{C}$ dan mendekati dengan literatur, sedangkan titik leleh yang terendah pada perlakuan $20 \%$ sebesar $51,0^{\circ} \mathrm{C}$, seperti yang disajikan pada Tabel 3 dan grafik korelasi volume pelarut dan titik lelehnya dapat disajikan pada Gambar 8.

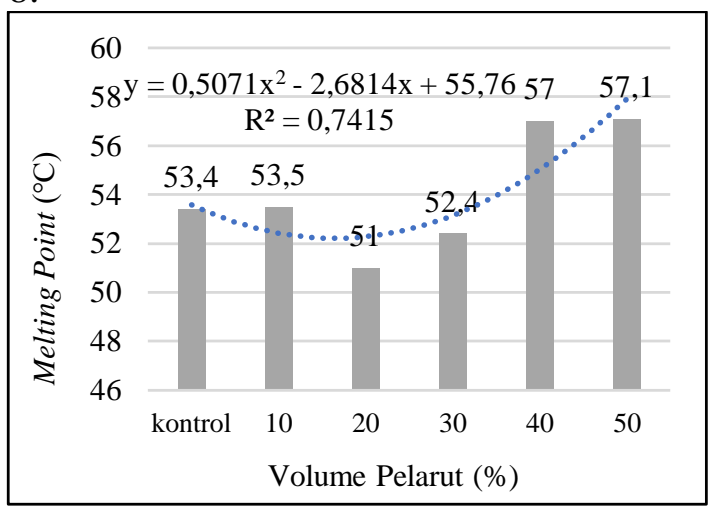

Gambar 8. Grafik Hasil Uji Melting Point

Tabel 3. Hasil Pengujian Melting Point Kristal Pathcouli Alcohol

\begin{tabular}{ccc}
\multicolumn{3}{c}{ Kristal Pathcouli Alcohol } \\
\hline No. & $\begin{array}{c}\text { Perlakuan } \\
\text { Volume } \\
\text { Pelarut }\end{array}$ & Titik Leleh \\
\hline 1 & Kontrol & 53,4 \\
2 & $10 \%$ & 53,5 \\
3 & $20 \%$ & 51,0 \\
4 & $30 \%$ & 52,4 \\
5 & $40 \%$ & 57,0 \\
6 & $50 \%$ & 57,1 \\
\hline
\end{tabular}

Nilai koefisien determinasi $\left(\mathrm{R}^{2}\right)$ dari persamaan polynomial adalah 0,7415 dan nilai regresinya 0,8611 atau $86,11 \%$, nilai regresi berada pada rentang 0,71-0,90 artinya keeratan korelasi antara nilai volume pelarut dengan titik lelehnya kuat sekali. Hal ini dapat disebabkan oleh bentuk kristal yang terbentuk pada setiap perlakuan berbeda. Menurut Gracesella dan Sopyan (2016), ukuran kristal yang terbentuk mempengaruhi dalam menentukan titik lelehnya. Apabila semakin besar ukuran kristal yang digunakan, maka semakin lambat terjadinya pelelehan.

\section{KESIMPULAN DAN SARAN}

\section{Kesimpulan}

Volume pelarut sangat mempengaruhi rendemen yang dihasilkan, dimana semakin banyak pelarut yang digunakan maka semakin sedikit rendemen yang dihasilkan. Perlakuan volume pelarut $10 \%$ merupakan kondisi terbaik dengan nilai rendemen kristal $52,77 \%$ dan yield $87,93 \%$. Mutu kristal patchouli alcohol juga sangat dipengaruhi oleh volume pelarut. Perlakuan terbaik untuk warna pada perlakuan volume pelarut $50 \%$ dengan nilai Hue 100,0533, true density pada perlakuan $30 \%$ yaitu $1,011 \mathrm{~g} / \mathrm{mL}$, dan melting point pada perlakuan $40 \%$ yaitu $57^{\circ} \mathrm{C}$.

\section{Saran}

Saran yang dapat diberikan pada penelitian ini adalah perlu dilakukan analisis lanjutan mengenai mutu kristal patchouli alcohol untuk mengetahui karakterisasi struktur kristal, dan ukuran kristal dengan menggunakan XRD (X-Ray Diffraction).

\section{DAFTAR PUSTAKA}

Armando, Rochim. (2009). Memproduksi Minyak Atsiri Berkualitas. Cetakan I. Penerbit Penebar Swadaya. Jakarta

Dewan Atsiri Indonesia dan IPB. (2009). Minyak Atsiri Indonesia. Editor: Dr. Molide Rizal, Dr. Meika S. Rusli dan Ariato Mulyadi.Terdapat 
pada:

https://minyakatsirindonesia.wordp ress.com/2009/06/10/minyakatsirii ndonesia (Diakses pada tanggal 27 Juli 2018 pukul 12.15 WIB).

Gracesella, Cyntia., dan Sopyan, Iyan. (2016). Ko-Kristal di Bidang Farmasi:review jurnal. Jurnal Farmaka. Vol. 14 (1) : 63-79.

Guenther, Ernest. (1990). Minyak Atsiri jilid IV (terjemahan). S. Ketaren dan R. Mulyono. UI Press. Jakarta.

Hashilah, C. (2017). Kajian Pengaruh Variasi Tekanan pada Distilasi Fraksinasi Terhadap Peningkatan Kadar Patchouli alcohol dalam Minyak Nilam (Pogostemon cablin Benth). [Skripsi] Fakultas Teknologi Industri Pertanian. Universitas Padjadjaran.

Hojjati, H., dan Rohani, S. (2005). Cooling and Seeding Effect on Supersaturation and Final Crystal Size Distribution of Ammonium Sulphate in A Batch Crystallizer. Chemical Engineering and Processing, Vol. 44 (4): 949-957.

Mahfud dan D. S. Bhuana. (2010). Peningkatan Mutu Produk Minyak Nilam Melalui. Kristalisasi Patchouli Alcohol. [Penelitian Guru Besar] Institut Teknologi Sepuluh Nopember. Surabaya.

Nurjanah, S., Rosi, D.M., Fathoni, R.P., Laeli, Sudaryanto, Widyasanti, A., dan Putri, I.L.K. (2016). Uji Aktivitas Antibakteri Minyak Nilam (Patchouli oil) Hasil Fraksinasi. Konferensi Nasional Minyak Atsiri IV. Banda Aceh.

Nurjanah, S., M. Muhaemin, dan A. Widyasanti. (2017). Laporan Akhir Tahun : Rekayasa Produksi Nilam Kristal Guna Meningkatkan Ekspor Komoditi Hilir Minyak Atsiri. Universitas Padjadjaran. Jatinangor.

Rahman, M. Shafiur. (2009). Food Properties Handbook. 2nd edition. Taylor and Francis Group. America.

Sarwono, B. 1998. Budidaya Nilam di Purbalingga. Trubus 343-Th CCIXJuni 1998. Hal 77-78.

Setiyowati, H., dan Fitri, N. (2012). Peningkatan Kualitas Minyak Nilam dengan Modifikasi $\mathrm{pH}$ Air Penyuling. Indonesia Journal of Chemical Research. Vol. 1(1): 1825.

Tung, H., Paul, E.L., Middler, M., and McCauley, J.A. (2009). Crystallization of Organic Coumpounds: An Industrial Perspective. John Willey \& Sons, Inc. New Jersey.

Widyanto, D., dan Nugroho, P. S. (2010). Pengaruh Kecepatan Pengaduk dan Volume Pelarut Pada Kristalisasi Patchouli alcohol dengan Metode Destilasi Vakum. [Skripsi]. Fakultas Teknologi Industri. Institut Teknologi Sepuluh Nopember. Surabaya. 